\title{
Ecotourism in Annapurna Conservation Area: Potential, Opportunities and Challenges
}

\author{
Bishow Poudel $^{1}$, Rajeev Joshi*1, 2 \\ ${ }^{1}$ Faculty of Forestry, Amity Global Education (Lord Buddha College), CTEVT, Tokha-11, Kathmandu- \\ 44600, Nepal \\ ${ }^{2}$ Forest Research Institute (Deemed to be) University, Dehradun-248195, Uttarakhand, India \\ *Corresponding author: joshi.rajeev20@gmail.com | ORCID: https://orcid.org/0000-0003-1106-9911
}

How to cite this paper: Poudel, B. and Joshi, R. (2020). Ecotourism in Annapurna Conservation Area: Potential, Opportunities and Challenges. Grassroots Journal of Natural Resources, 3(4): 49-73. Doi: https://doi.org/10.33002/nr2581.6853.03044

Received: 22 September 2020

Reviewed: 14 October 2020

Provisionally Accepted: 19 October 2020

Revised: 01 November 2020

Finally Accepted: 18 November 2020

Published: 20 December 2020

Copyright $@ 2020$ by author(s)

This work is licensed under the Creative Commons Attribution International License (CC BY 4.0).

http://creativecommons.org/licenses/by/4.0/
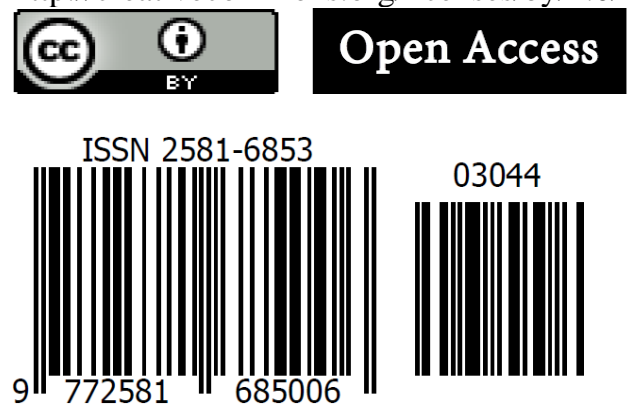

\begin{abstract}
Ecotourism as a component of the sustainable green economy is one of the fastest growing segments of the tourism industry, because of its superiority compared to other types of tourism in terms of the responsibility towards people, nature and environment. In the long run, people can also be benefitted from ecotourism. This research explores the fundamental potential, challenges and opportunities of developing ecotourism in Ghorepani village of Annapurna Conservation Area (ACA), the first and largest mountainous protected area in Nepal. Primary data were collected through preliminary field visit, questionnaire survey of households, key informant interviews, focus group discussion and direct field observation. The Ghorepani village of ACA attracts many tourists because of its beautiful natural landscape, biodiversity richness, snow-capped mountains, sunrise from Poon hills and different Rhododendron forests. Overall, the key finding of this article outlines the current status, potentials, strengths, weakness, opportunities and challenges in ecological tourism development. On that basis, Ghorepani village of ACA needs to be improved with multiple outreach activities, especially to resource-dependent households.
\end{abstract}

\section{Keywords}

Biodiversity; Ecotourism development; Local people; Nature based tourism; Sustainable development 


\section{Introduction}

Tourism has become a rapidly growing market and its development brings many benefits to developing countries showing remarkable growth in the current global scenario (UNWTO, 2010). Moreover, tourism is a sustainable green economy that has an enormous contribution to local economies, job creation and sustainable development, which helps to improve the human wellbeing and social equity by reducing environmental risks and ecological scarcities (Sukhdev, Stone and Nuttol, 2010; Beza and Berhan, 2017). However, it also brings negative economic, sociocultural and environmental impacts as it only focuses on immediate economic benefits without the necessary management and conservation of natural resources leading to impulsive consequences of society, culture and the environment (Tseng et al., 2018). The close relationship between tourism and environment has added a new dimension to tourism called 'ecotourism' or 'eco-friendly' tourism. According to the definition presented by the International Ecotourism Society (TIES) in 1991, ecotourism means "responsible travel to natural areas that conserves the environment and improves the well-being of local people". It is a form of the sustainable tourism and differs from other forms of tourism because of its principles as identified by Hetzer (1965). It minimizes environmental impacts, respecting host culture, maximizing the benefits to local people and maximizing tourist satisfaction (Blamey, 2000). Ecotourism is the fastest growing sector in the tourism industry (Weaver, 2001a; Lamsal, 2011). Ecotourism is also a form of tourism that fosters learning experiences and appreciation of the natural environment, or some components thereof, within its associated cultural context (Weaver, 2001b). It is a timely strategy that is vital to the maintenance of healthy ecosystems along with economic benefits to any host area communities (Yogi, 2010). Ecotourism is one of the fastest growing forms of tourism that guarantees the sustainable use of environmental resources, while generating economic opportunities for the local people (Nguyen, 2020; Farrell and Runyan, 1991; Bhattacharya, Choudhury and Sarkar, 2012). Ecotourism is a part of nature tourism but most of the people often confused with sustainable tourism and consider them as synonyms. Ecotourism activities are strongly associated with adventure tourism and cultural tourism offered by a large and wide diversity of operators and tourists (Cater and Cater, 2015; Lee and Jan, 2019; Poyyamoli, 2018). However, sustainable tourism helps to meet the needs of the present tourists and host regions while protecting and enhancing opportunity for the future (Poyyamoli, 2018).

Nowadays, the increasing number of parks, trekking areas and natural settings are becoming popular tourist destinations (Smolčić Jurdana, 2009). Villages, forests, national parks and other protected areas have a well-established connection with ecotourism (Butler and Boyd, 2000). The development of ecotourism in village can help increase influx of tourists. With the good hospitality and concept of homestay, greater amount of foreign exchange can be earned (Singh and Upadhyay, 2011). Specifically, tourism offers a great opportunity for developing countries like Nepal through employment opportunities to the unskilled workforce, and by providing unique and natural environment it attracts entrepreneurs and organizations to the countryside and remote protected areas (Nepal, 1997; UNEP, 2013). Likewise, tourism is recognized as a major user of biological resources and source of employment for many Nepalese, who contribute significantly to the economy (Shrestha, 2001). Ecotourism contributes to GDP at national level by nearly 2 percent (MoTCA, 2012). Nepal is a small landlocked country having a great diversity of topographic and eco-climatic features rich in natural resources and cultural heritage, which are valuable economic assets for ecotourism (Bhusal, 2007). Rural areas in Nepal are the most adventurous cultural and ecotourism destinations in the world, which depend on the quality of the natural environment of 
the countryside (Nepal, 1997). Community-based rural ecotourism is experience-oriented supporting the livelihood of local communities by providing opportunities to the national and international visitors (Acharya and Halpenny, 2013). Hence, the Government of Nepal has promoted national parks, buffer zones, wildlife reserves, conservation areas and cultural sites for conserving biodiversity and enhancing ecotourism (Baral, Stren and Hammet, 2012). Now, it can be one of the newest opportunities for income generation from natural resources without destroying and disturbing the environment and local cultures, contributing to the economic wellbeing of local communities and the stakeholders (Cusack and Dixon, 2006).

In the past, the Government of Nepal has also identified ecotourism as a strong sector contributing significantly to employment generation, revenue collection, environmental conservation and socioeconomic development (Acharya and Halpenny, 2013). However, limited research has been carried out on this topic in the context of Nepal. Therefore, this study was conducted with an objective to identify impacts of ecotourism in the area assessing its opportunities and challenges, especially focusing on biodiversity conservation and management, problems for ecotourism management and enhancement of livelihoods of the local people analyzing their perceptions on ecotourism development. The study was conducted in the Ghorepani village of Annapurna Conservation Area, Nepal. The knowledge and information thus obtained from this study might be useful to find out how the communities are managing natural and cultural heritage for the enhancement of their livelihood.

\section{Materials and Methods}

\section{Study area}

The study was carried out in Ghorepani village of Annapurna Conservation Area (ACA), which lies in Annapurna rural municipality (ward no. 6) of Myagdi district (Figure 1). Myagdi district is located in Dhaulagiri zone of north-western part of Gandaki Province, Nepal. Ghorepani village lies at the geographical location of longitude $83^{\circ} 41^{\prime} 57^{\prime}$ ' $\mathrm{E}$ and latitudes of $28^{\circ} 23^{\prime} 55^{\prime}$ ' $\mathrm{N}$. The study area is almost $17 \mathrm{~km}$ away from the district headquarter (Beni) of Myagdi and situated at the elevation of approximately 2,874 masl. Ghorepani village is located within the Annapurna Conservation Area and contains several guest houses that provide lodging and meal to mountain trekkers, many of whom spend the night before a pre-dawn trek to the top of nearby Pun Hill (3,210 m) meant to watch the sunrise. Due to the immense natural view, spectacular snowcapped mountains, beautiful forest, hills and wildlife, this village is well known as a tourist destination both inside and outside the country. Both national as well as international tourists visit this area for trekking and mountaineering purposes. The main reasons for visiting this area by tourists is to enjoy traditional culture, to observe the scenic beauty of the Himalayan range, to take a hot water bath in the hot springs, and to enjoy the scenic beauty of natural resources. The village of Ghorepani is also famous for its interesting culture and tradition that has also helped Ghorepani to draw a large number of tourists. Ghorepani is a small village with maximum opportunities where many tourists visit in spring and autumn season due to which many challenges are still present in the study area to maintain the environment and natural resources. 


\section{Study Area}
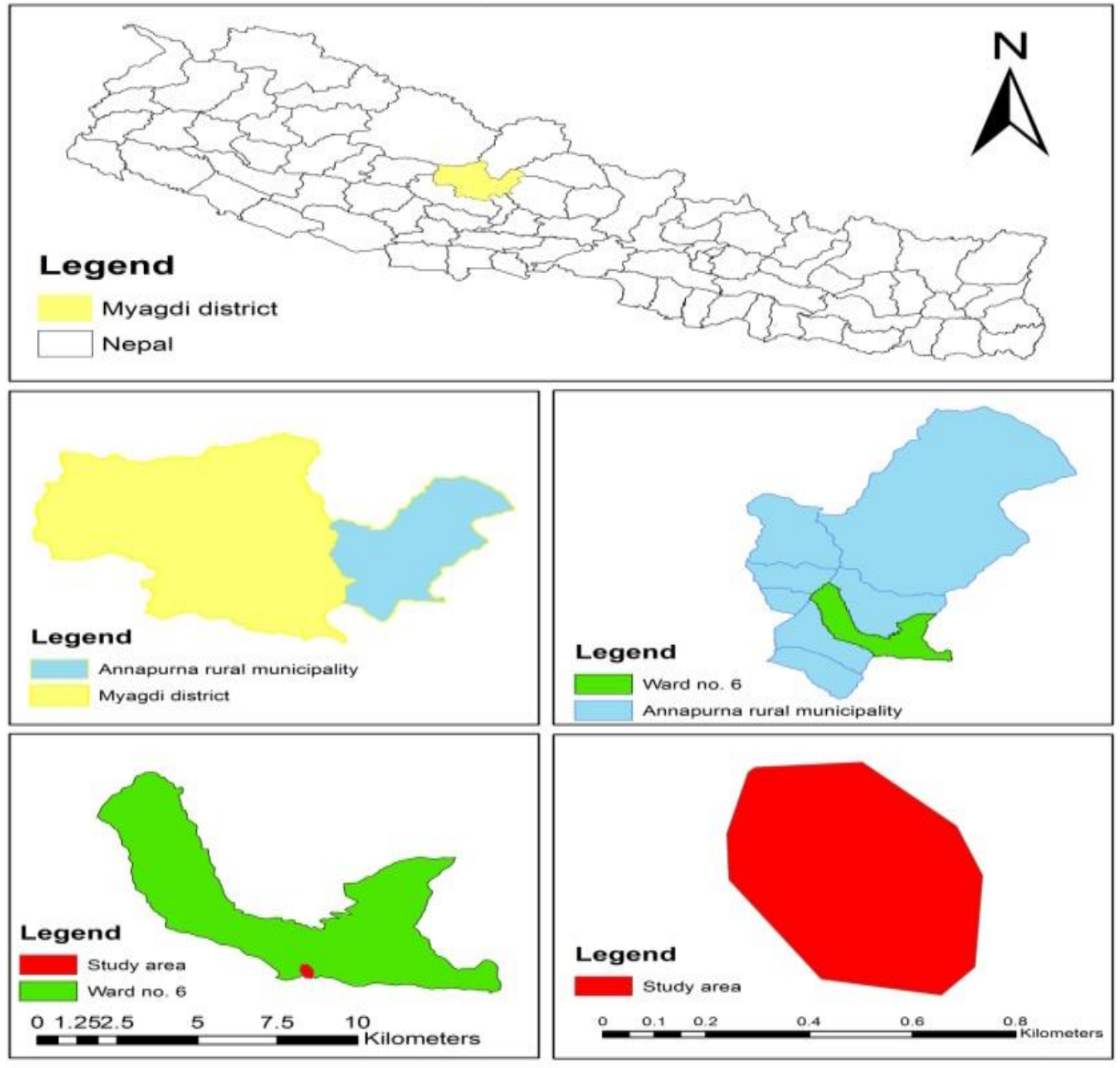

Figure 1: Map of the study area

\section{Sampling Design and Data Collection}

The field study was carried out during the tourist season between April and May 2018, which was favourable for visiting the local people as they are relatively free from agricultural activities. Due to the smaller number of households in the study area, 100 percent households involved in tourism and non-tourism business were surveyed by using the random sampling method. Tourists residing in the study area at the time of study were surveyed to know the visitors' satisfaction level and activities they liked. During the field visit, we were able to sample only 50 visitors. They belonged to different countries, such as Nepal, China, Germany, Norway, USA, India, France, Spain, Australia and Canada. Both quantitative and qualitative approaches were used to extract reliable data. The primary data was collected by employing combination of social survey methods involving participatory rural appraisal (PRA) tools and techniques, such as onsite field observation, questionnaire-based households surveys $(n=98)$, key informant interview, and focal group 
discussions, along with other socio-economic details that were collected through a semi-structured questionnaire. Visitors to the village at least once in the particular year were sampled for the survey.

The villagers involved in tourism activities were interviewed directly. This survey was carried out to acquire relatively detailed information on local people's perception in ecotourism, socioeconomic status of the users, biophysical situation of the site, opportunities, problems of ecotourism. To discuss the opportunities and problems of ecotourism in the study area and to gather information related to ecotourism management activities, tourist attraction centres, income and employment opportunities from ecotourism activities, issues and constraints of ecotourism, key informants like Ghorepani executive committee members involved in tourism business, local teachers, police check post and divisional forest office (DFO) staff were interviewed. The main sources of secondary data were Ghorepani trek management plan, various books, research reports, journals, articles, Ministry of Culture, Tourism and Civil Aviation (MOTCA), Tourism Office Pokhara (TOP), Annapurna Conservation Area Project (ACAP), Department of National Park and Wildlife Conservation (DNPWC) and Nepal Tourism Board (NTB), which included both published and unpublished reports.

\section{Data Analysis}

Qualitative and quantitative data were analyzed with the help of statistical package MS Excel and SPSS version 22. People's perception and visitors' satisfaction were assessed with the use of 5point Likert scale and later converted to 3-point Likert scale, followed by Chi square test to analyze the data. Three variables such as gender, ethnicity and education were taken for assessing people's perception and three variables - gender, age class and education - were taken for assessing visitors' satisfaction. The findings were interpreted in the final report in a suitable form such as charts, tables, graphs, etc.

\section{Result and Discussion}

\section{Socio-economic information of the respondents}

Socio-economic information of the respondents such as gender, ethnicity, education, occupation and age class contribute towards ecotourism participation in this study.

\section{Gender of the respondents}

Out of the 98 respondents surveyed, 55 percent of the respondents were female, and 45 percent of the respondents were male. Gender wise, there were more female respondents than the males. This is similar to the findings of Nath and Alauddin (2006) and Khatri-Chhetri, Rijal and Sapkota (2015). To avoid the gender bias, survey was based on the availability of the household members during the field visit. However, the proportion of male to female respondents represented was still female-biased (Figure 2). Although, the Nepalese society is male dominated, female respondents' participation was relatively high because men were employed out in the city or abroad to earn money. Hence, females were found more actively involved in ecotourism activities. The household survey interview was conducted with respondents having the age between 18 to 60 years. 


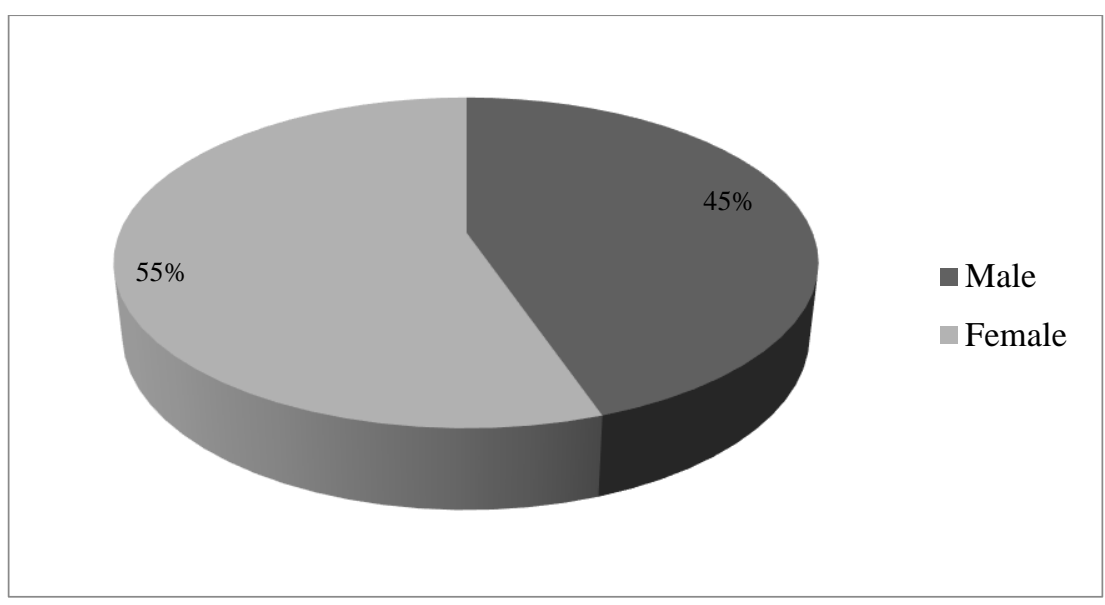

Figure 2: Gender of the respondents

\section{Ethnicity of the respondents}

In the study area, respondents comprise of three major ethnic groups i.e., Gurung/Magar, Brahmin/Chhettri and Others. Of the total respondents, most of the respondents (76 percent) consisted of the ethnic group of Gurung/Magar, 5 percent were Brahmin/Chhettri and 19 percent were others (Figure 3). However, most of Gurung/Magar were found involved in ecotourism business. Hence, in the studied area, Brahmin/Chettri and other ethnic groups were observed economically weaker compared to Gurung/Magar ethnic group.

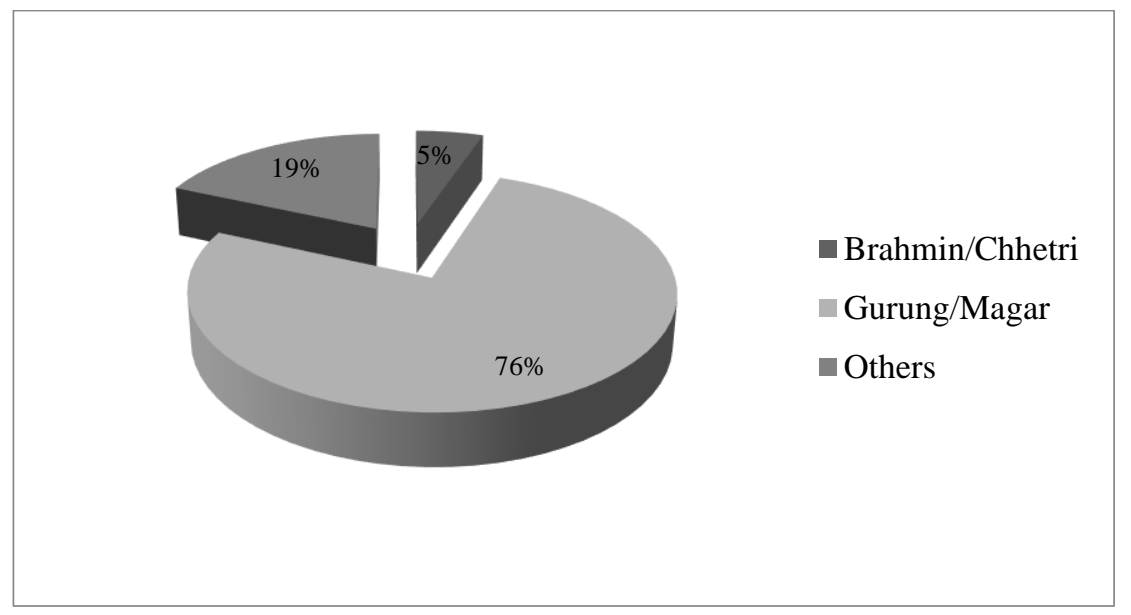

Figure 3: Ethnic composition of the respondents

\section{Education level of the respondents}

Education level of respondents was categorized into three groups: illiterate, high school and college educated (Figure 4). Among the respondents, about 37 percent of the respondents were illiterate and 50 percent had high school education (literate), which is comparable to the study conducted by Amati (2013) in Kimana Community Wildlife Sanctuary (KCWS), Kenya (52.5 percent) and less than the study performed by Khatri-Chhetri, Rijal and Sapkota (2015) in Annapurna Conservation Area of Nepal (75.2 percent). There were very less respondents who pursued higher education (13 percent), which is more than that reported by Khatri-Chhetri, Rijal and Sapkota (2015) in 
Annapurna Conservation Area, Nepal (6.2 percent). Majority of the people in the study area were literate and those literate people were observed more involved in tourism business than the illiterate people (Figure 4). The literacy rate of the respondents was found less than the national literacy rate of population of Nepal (65.9 percent) (CBS, 2012). Education level of the respondents cannot be considered as the effect of ecotourism; However, it can be said that education level reflects the respondent's insight on subject matter.

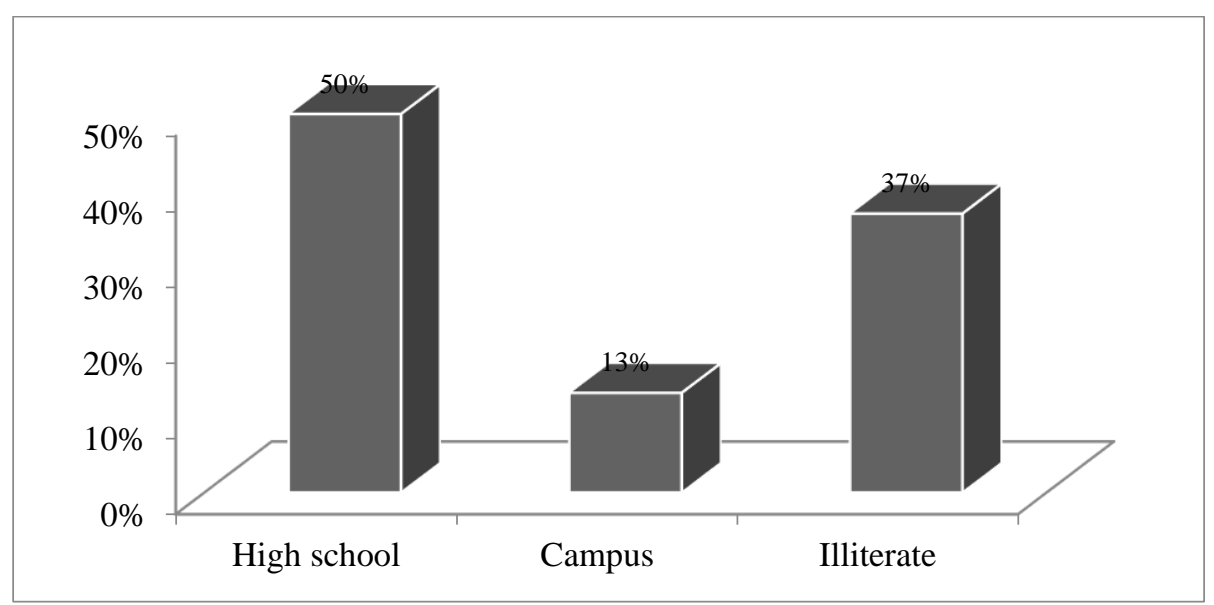

Figure 4: Education level of the respondents

\section{Occupation of the respondents}

As the study area lies in the hilly region of Nepal, most of the households in the study area were involved in tourism business activities (79 percent), which is higher than the study of KhatriChhetri, Rijal and Sapkota (2015) (38.8 percent). Similarly, 5 percent of the people found engaged in agriculture, 3 percent had private/government services and 13 percent had other occupations (Figure 5). Only during plantation and harvesting time, 5 percent of households were found engaged in agriculture, and during rest of the times they were engaged in tourism business. Very few households were involved in service ( 3 percent), which was less than in the study of KhatriChhetri, Rijal and Sapkota (2015) (14.5 percent) and Nath and Alauddin (2006) (30 percent), indicating that the people in the study area depend directly on tourism and other occupations for sustaining their livelihood.

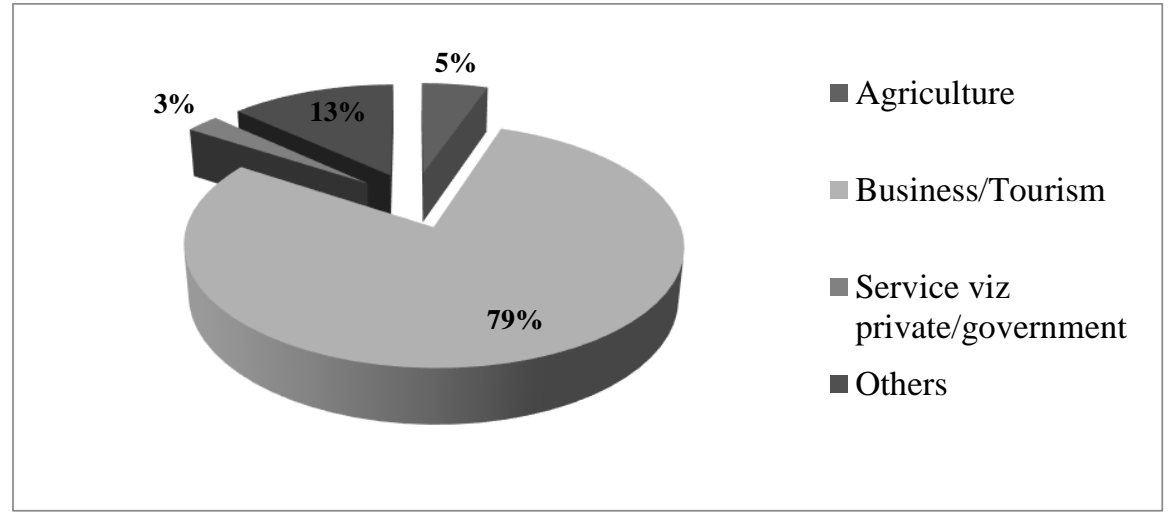

Figure 5: Occupation of the respondents 


\section{Age of the respondents}

Based on their age, respondents were classified as young aged (up to 25 years), medium aged (2645 years) and old aged (above 45years). As shown in figure 6, 71 percent of the respondents were middle aged, 18 percent were of young aged and 11 percent were of old aged. Majority of the respondents were of age between 35 and 45 years.

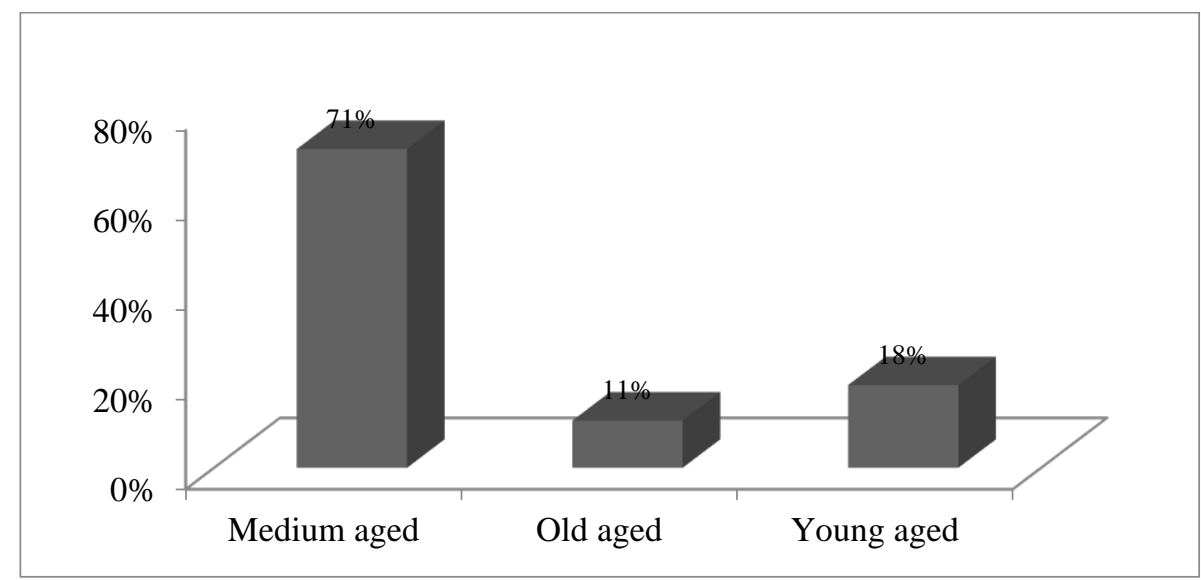

Figure 6: Age of the respondents

\section{Tourism related information}

\section{Status of tourism}

Out of 98 respondents, 11 percent of respondents said that the status of tourism should be improved in the area. 76 percent said good and remaining 13 percent said very good (Figure 7). There were no records for the number of tourists visiting to the study area; however, majority of the respondents said that the tourism activity is decreasing this year compared to the previous years. They also pointed out the main reason is the political instability of Nepal and lack of marketing support. A large majority of the people also said that domestic tourists are increasing this year as compared to the past.

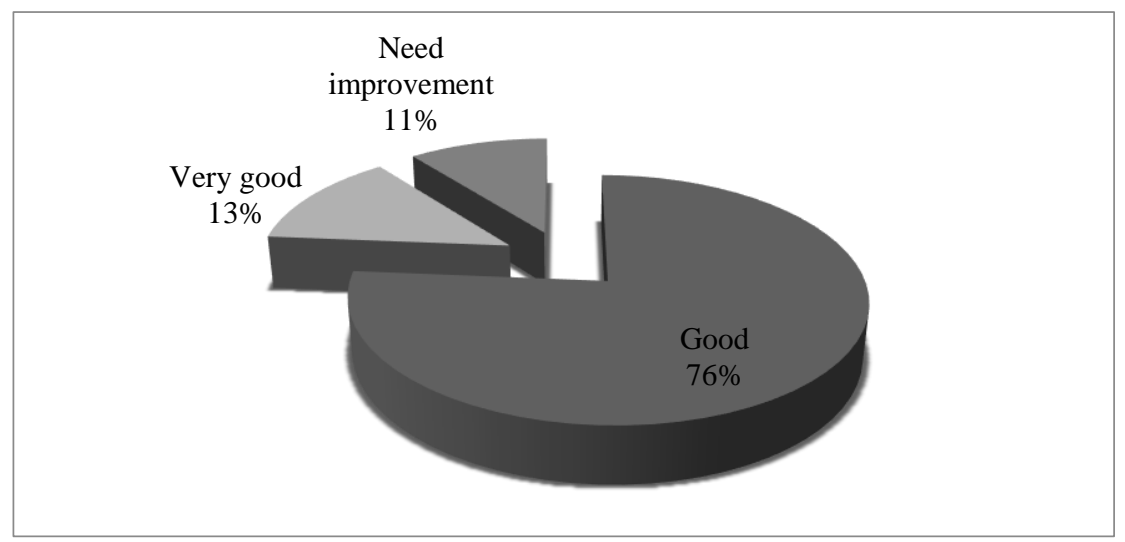

Figure 7: Status of Tourism 
The age groups of tourists were categorized into four groups: children (up to 15 years), youngster (16-25 years), adults (25 years and above) and all ages. About 39 percent of the respondents said that mostly adults visit this area; 11 percent of the respondents said that youngsters visit the area; 42 percent and 8 percent of the respondents said that tourists of all ages and children, respectively, visit this area mostly (Figure 8).

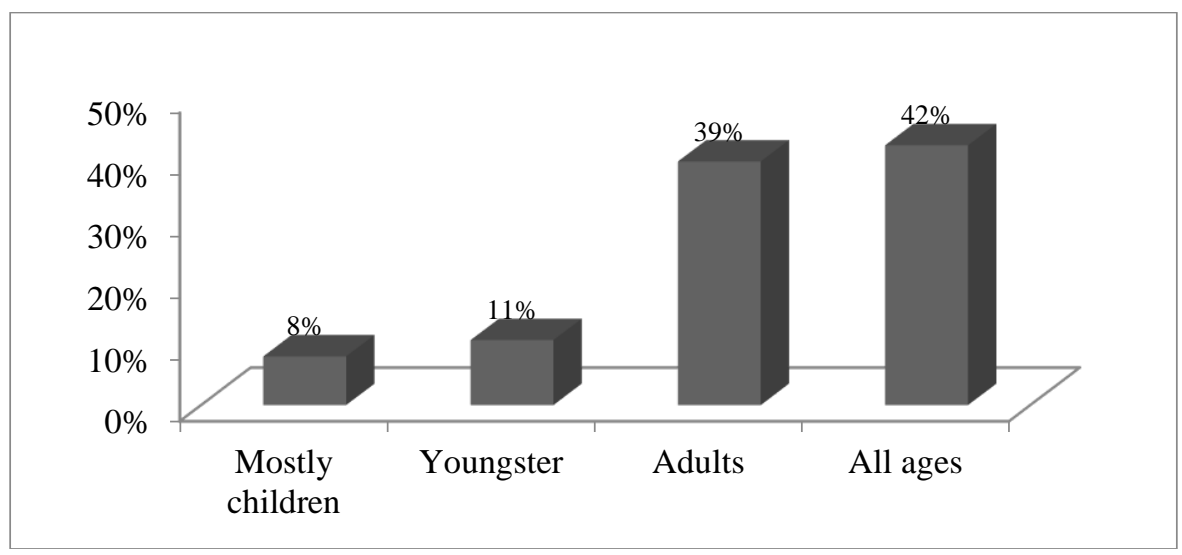

Figure 8: Age group of tourists

\section{Existing features/attractions and activities for ecotourism in Ghorepani village}

\section{Rich biodiversity}

Ghorepani area is rich in biodiversity. There are numerous flora and fauna that are attractions for tourists. Numerous species of Rhododendron existing here are the main attraction for tourists. Similarly, various species of plants and animals enhance the beauty of the area. Ghorepani village of Annapurna Conservation Area is home to 22 different types of forests with 1,226 species of plants (KMTNC, 1995). Among them, 55 plant species are endemic in nature. The various tree species such as Laligurans (Rhododendron arboreum), Chilaune (Schima wallichii), Katus (Castanopsis indica), Utis (Alnus nepalensis), Gobre Salla (Pinus wallichiana), Bhojpatra (Betula utilis) are found in this area. Similarly, this area is habitat to about 101 species of mammals including endangered species like snow leopard (Panthera uncia), musk deer (Moschus moschiferus), Tibetan argali (Ovis hodgsoni) and Tibetan wolf (Canis lupus chanco). This is the only area where all 6 Himalayan pheasants of Nepal such as Impeyan Pheasant (Lophophorus impejanus), Crimson Horned Pheasant (Tragopan satyra), Cheer Pheasant (Catreus wallichii) are found. These rare and endemic flora and fauna can be the attraction for tourists. Snow-capped mountains are also the main attraction for the tourist in the area. Ecotourism plays a crucial role in natural resource and biodiversity conservation (Amati, 2013; Cao et al., 2014), which can also be seen in Ghorepani village. The main environmental components improved by ecotourism in Gorepani village are an increase in forest cover, conservation and management of flora and fauna, an increase in greenery and use of alternative energy sources, which are similar to the study of Khatri-Chhetri, Rijal and Sapkota (2015) in Nepal, Winson (2006) in Cuba and Zambrano et al. (2010) in Osa Peninsula, Costa Rica. Ecotourism has huge potential to generate direct and indirect community benefits from conservation activities, as the studies of Ormsby and Mannle (2006) and 
Khatri-Chhetri, Rijal and Sapkota (2015) indicate. The income generated by ecotourism also helps in environmental conservation in Ghorepani village. It resembles the findings of Cheung and Jim (2014) and Khatri-Chhetri, Rijal and Sapkota (2015).

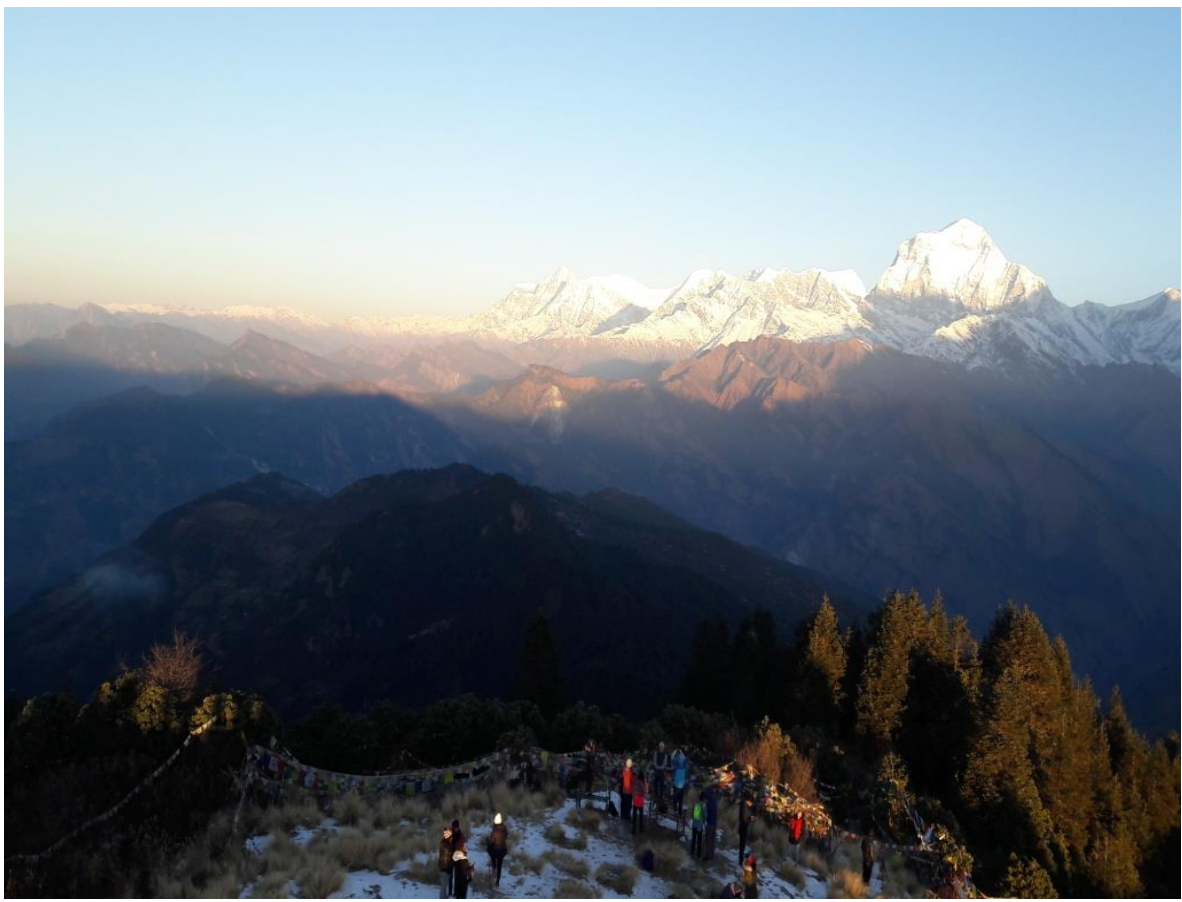

Figure 9: Rich biodiversity with snow-capped mountains

\section{Trekking}

Nepal is the ultimate destination for the trekking enthusiasts. The mountain terrain offers a myriad of possibilities. Nepal has aptly been called "A Trekkers Paradise" because the hilly terrain offers some of the most spectacular trekking routes in the world. There are best stony foot trails with signs by Annapurna Conservation Area Project (ACAP) along the Ghorepani route where the visitors can trek and enjoy. There are various trekking routes in which many tourists trek during the daytime. It is the best trekking route in Nepal.

\section{Hotels/homestays}

Homestay is a type of tourist accommodation that differs from typical house accommodation commonly found in communities. Homestay offers the traveler a unique local experience that combines basic needs of food and shelter, and possibilities of interaction with the host family. The guest can interact with host families, and can understand the local culture, traditions and customs. Homestays are soothing destinations for couples, family and even singles who desire a private peaceful holiday. There are more than five homestays in Ghorepani Village. Similarly, there are numerous hotels for the tourists in the area. 


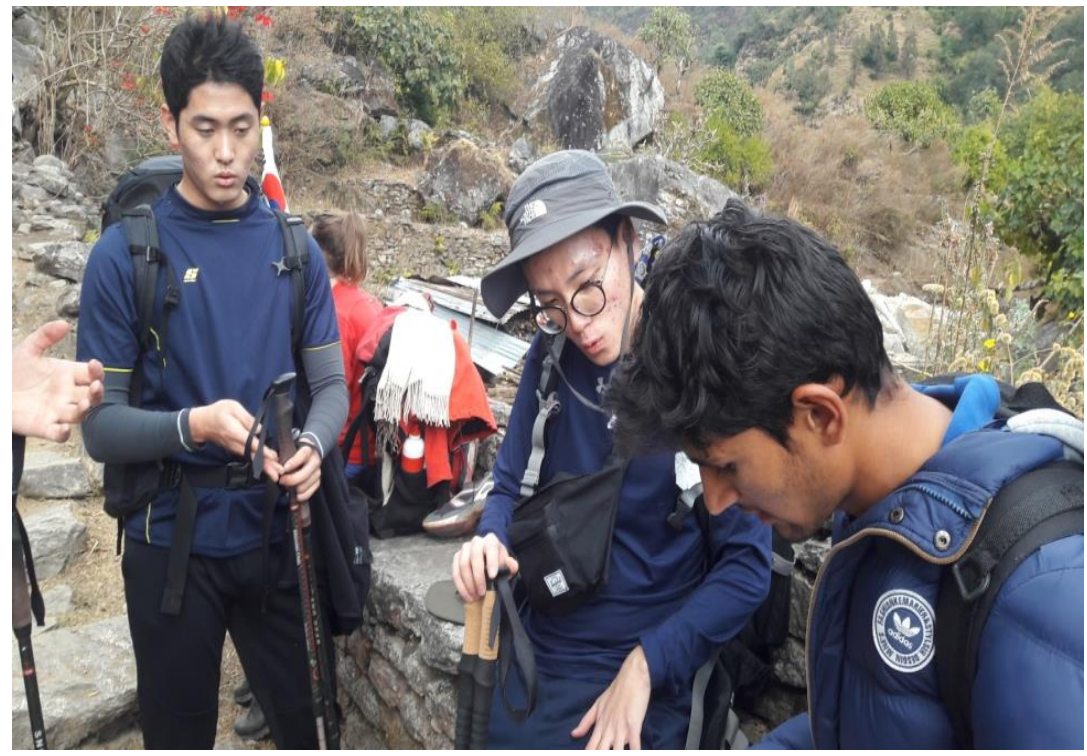

Figure 10: Interview with tourists

\section{Camping}

Camping is an optional outdoor recreational activity. Generally, tourists spend time outdoor in natural area with the aim of recreation. The "camping" requires minimum of one night to be spent outdoor, distinguishing it from day-tripping, picnicking, and other similar short-term recreational activity. Camping can be enjoyed throughout all four seasons. Ghorepani village offers good sites for adventurous camping to both domestic and international tourists.

\section{Research centre}

Ghorepani village has been a research platform for numerous researchers. Students and other researchers visit Ghorepani area for studying various plants and animals. Much research in ecotourism related activities have been carried out in this area recently. However, there are still many resources and objects that need to be explored and researched in this area.

\section{View tower}

There is a view tower within 45-minute walk from the Ghorepani village at the height of 3,210 m. It is called Poon hill. The view from the top is breathtaking. Mountain range visible from Panchase hill includes Mt. Dhawalagiri (8,172 m), Mt. Annapurna I (8,091 m), Mt. Annapurna South (7,219 m), Mt. Fishtail (6,993 m), Mt. Annapurna II (7,934 m), Mt. Annapurna III (7,575 m), Mt. Annapurna IV $(7,525 \mathrm{~m})$ and Mt. Lamjung $(6,998 \mathrm{~m})$. It also provides the panoramic view of the sunrise and sunset, and area of wilderness.

\section{Local people's views on existing opportunities}

When the local people were asked about these opportunities, majority (50 percent) of the people said that they preferred the trekking most. 26 percent of the people said they preferred to look over the snowcapped mountains and natural scenery of Rhododendrons. 8 percent people said they 
visited due to good homestays, 5 percent said that they visited for camping, 8 percent said that the tourists visit to look over the view tower and 3 percent said the tourists visit for the educational purposes (Figure 9).

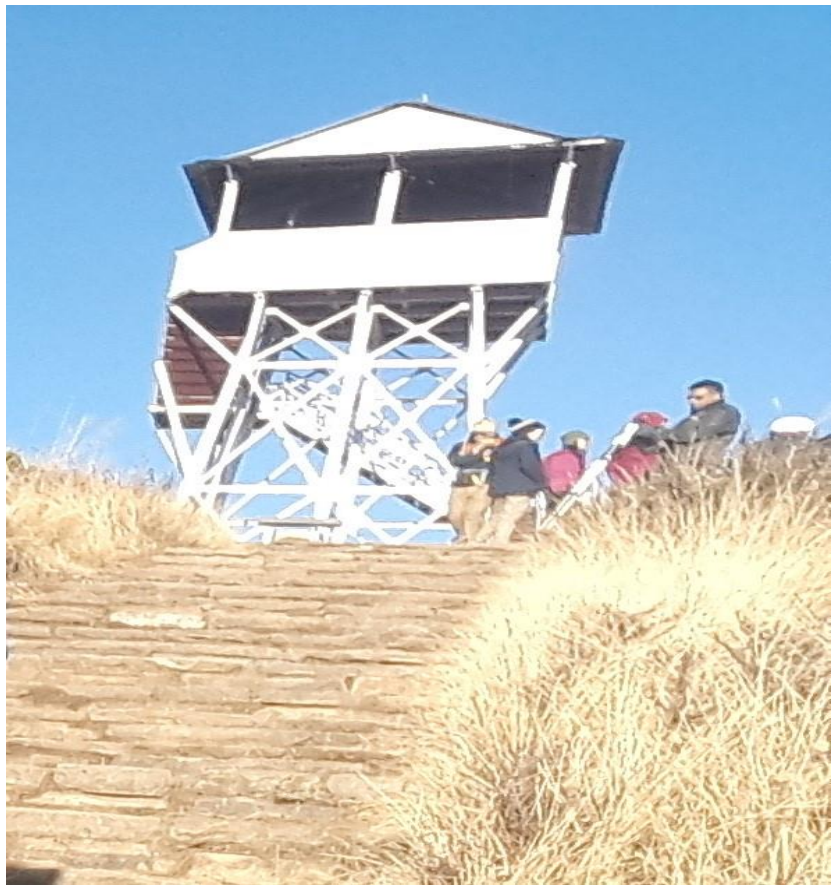

Figure 11: View tower of Ghorepani village

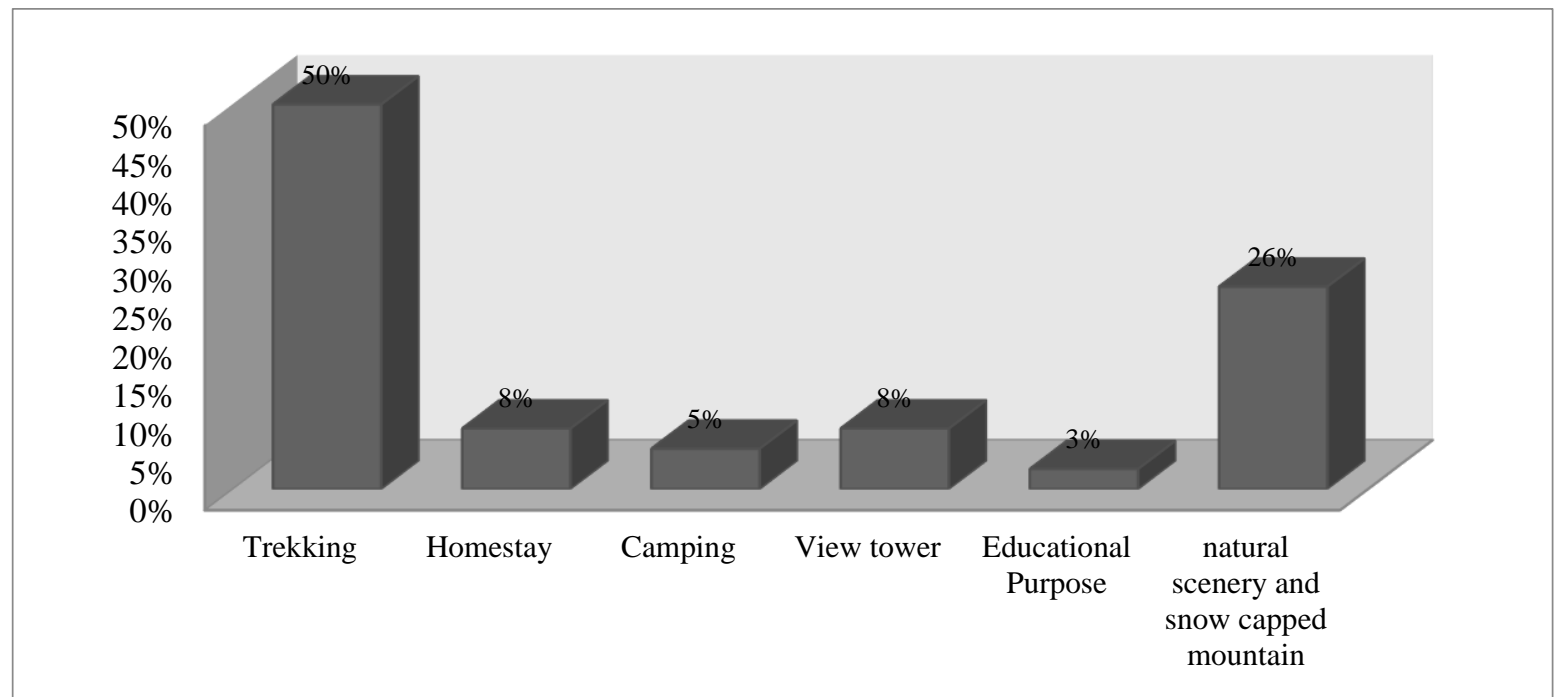

Figure 12: Local's view on existing opportunities

\section{Additional opportunities of ecotourism in the area}

\section{Cultural shows and programs}

People of different castes and religions reside in the Ghorepani village, in which the dominant ethnic groups include Magar, Gurung, Brahmin, Chhettri and Bishwakarma, while Hinduism and 
Buddhism were the main religions. Most of the Magar and Gurung communities are followers of Buddhism religion while other communities are followers of Hinduism religion. They have distinct cultures that are worth attracting tourists. The people exhibit their culture and dances to tourists to some extent, but they have limited knowledge in presenting and managing it more professionally. Organizing various cultural shows and dances in the form of programs such as "Ghatu dance", "Maruni dance", "Salaijo Bhaka" etc. can fascinate the visitors, ultimately increasing their number.

\section{The establishment of Magar museum}

Museums provide inspiration through personal connections with visitors. Museum offers not only on-site and through physical community outreach efforts; some even manage to connect through their social network. These kinds of personal memories created at museums do not diminish. The cultural museums depict one's culture, social values that can be a great deal of interest to the tourists. There is a Gurung museum in the Ghandruk village, which has attracted numbers of visitors. People of Ghorepani are also willing to establish a Magar cultural museum. Establishment of Magar museum can be a good opportunity for tourism in this area, as tourists are always memorized by unique cultures (Khatri-Chhetri, Rijal and Sapkota, 2015).

\section{Local people's views on additional opportunities}

When the local people were asked about these opportunities, majority (53 percent) of the people agreed on the idea of establishing Magar museum and thought that establishing a museum could benefit tourism in this area. 18 percent of the respondents were in favour of showing cultural and religious programs, 11 percent thought village walking would be a better opportunity and 18 percent of the respondents said that they do not know anything about this (Figure 10).

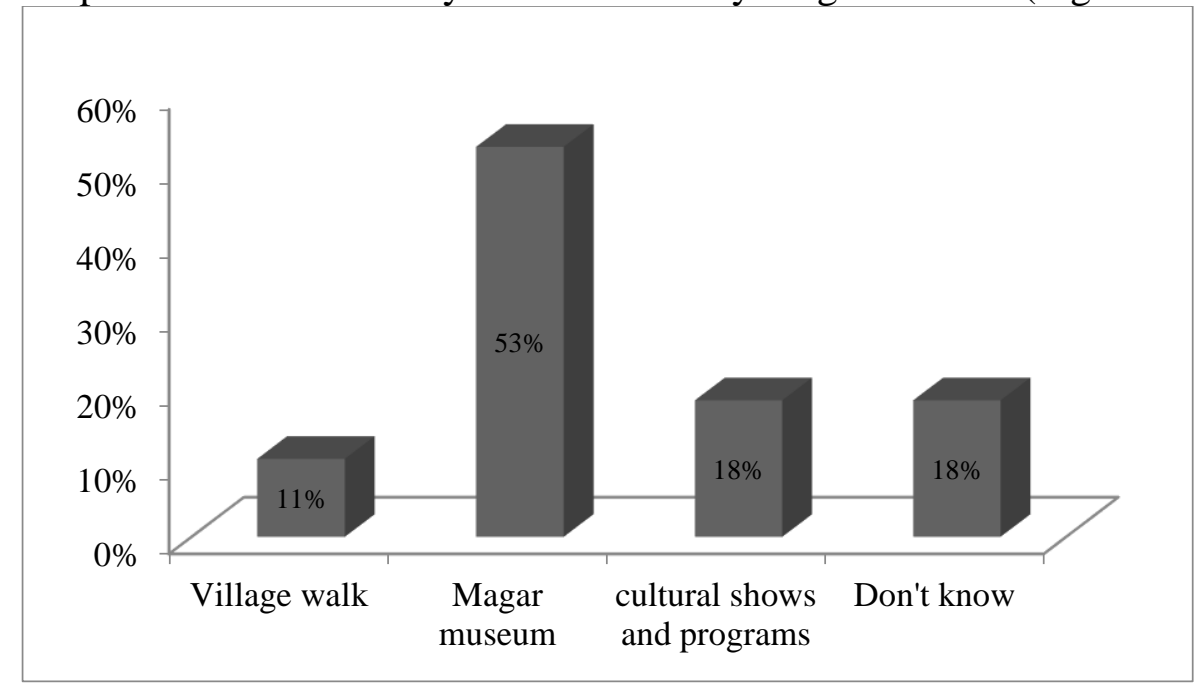

Figure 13: Local people's views on additional opportunities

\section{Problems for ecotourism development in the study area}

Though Ghorepani village and the surrounding area are beautiful places to visit, there are various constraints obstructing full-fledged development of ecotourism. Some of the issues of ecotourism development in the study area are explained under the subsequent subheadings. 


\section{No information centre and insufficient promotion}

The most important aspects of any business activity are information and advertisement. As tourism is in early stage in the area, there is no information centre. Most of the foreign tourists find it hard to acquire necessary information about Ghorepani. There is lack of system to show and communicate the information about religion, culture, activities for tourists, trekking routes, etc. of Poon hill. Due to this, Poon hill is unable to attract more tourists, especially the international tourists. Effective promotion and advertisements should be done through various tourism related organizations, travel agencies, etc.

\section{Lack of human resources in the village}

Another problem hindering ecotourism development is the lack of manpower in the village. The numbers of youths and males were found to be less in the village; thus, there is a lack of the manpower to be involved in ecotourism activities and management. For the successful development of ecotourism, there must be sufficient manpower involved in tourism business as well the people must have knowledge about ecotourism.

\section{Insufficient skill development trainings}

Proper conduction and management of ecotourism business and activities require good skills and knowledge. Though some interested people organizing homestays were given hospitality trainings in the area, trainings on other aspects are still lacking. Due to insufficient skill development trainings, there will be difficulty in ecotourism initiation and development. Skill development trainings such as training for guides, owners and workers of hotels and homestays should be given to enhance the ecotourism in the area.

\section{Insufficient infrastructures}

Another bottleneck for tourism in this area is old housing of the existing homestays. The houses are quite old and have insufficient accommodation in season. There are no proper toilet and bath facilities as well. Most of the international tourists have difficulty in this respect. There are no motor roads due to which domestic tourists are facing problems. These issues are somehow hindering ecotourism development in the area.

\section{Condition of the country}

This has been the major issue for ecotourism development in the area. According to the people in the study area, the number of tourists is decreasing this year as compared to previous years, due to the unstable situation of the country.

\section{Lack of awareness}

Lack of awareness among the local people regarding tourism is also an important factor that has created obstacle on tourism development in Ghorepani village and surrounding areas. Local people are not yet fully aware of the importance of their biocultural diversity and their natural resources. 


\section{Local people's views on the problems of ecotourism}

When the people were asked about the constraints for tourism development in the village, 34 percent of the people said that the main constraint of tourism is insufficient skill development training. About 21 percent of the respondents thought that lack of awareness is the main constraint. 18 percent thought that the condition of the country is an obstacle. On the other hand, 8 percent considered insufficient infrastructure as constraint, 5 percent considered insufficient advertisement as a constraint, and 3 percent considered lack of human resources in the village as major constraint. Finally, 11 percent of the respondents said that they do not know anything about this (Figure 11).

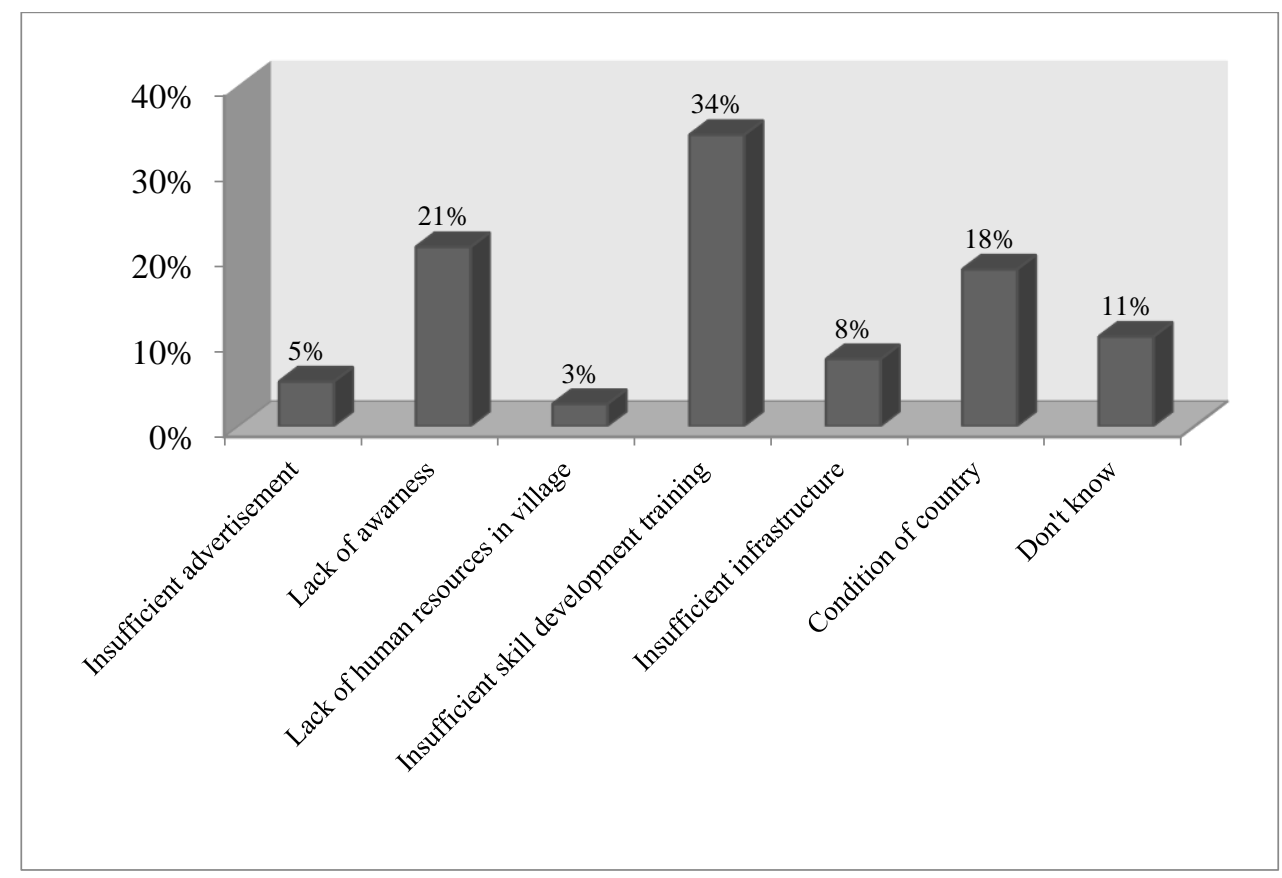

Figure 14: Local people's views on problems of ecotourism

\section{Tourism management activities}

Ghorepani village is seen as a prospective tourism site in recent years. Consequently, important tourism management activities have been conducted in the area. According to the information obtained from the police check post, local teachers, key informants and local people, some of the activities conducted include:

\section{Hospitality management training}

The management officials of Ghorepani village and Annapurna Conservation Area Project (ACAP) have provided hospitality training to the people involved in homestays and hotels business. Those people were trained about how to welcome domestic and international tourists, how to behave with visitors, and so on. But the management training is not enough for the people involved in tourism activities. Tourism activities mean involvement and participation of people in tourism related activities such as keeping small tea shops, providing catering, lodging and camping facilities, keeping horses and donkey for transporting goods and working as porters (Khatri-Chhetri, Rijal and Sapkota, 2015). Good hospitality management helps to generate employment opportunities 
from tourism participation that ultimately supports to earn more income (Stem et al., 2003). By providing good hospitality management in the tourism sector, the living standard of households can be enhanced compared to other non-participating households (Guha and Ghosh, 2007).

\section{Eco club formation}

Different eco clubs have been formed in local schools and village of Ghorepani. The members of clubs are responsible for conducting various awareness programs including tourism, cleanliness programs, etc. Similarly, the local people have initiated other groups like youth clubs, 'Aamasamuha' (Mother's group), 'Magarsamaj' (Magar association), etc. Such groups have conducted various programs like cultural shows, local trainings to youth about conservation, etc. These activities have directly and indirectly benefited tourism of the area.

\section{Cleanliness programs}

Cleanliness programs have been conducted by various clubs as well as local people in Ghorepani village. The local people have made groups including all households, and they are obliged to clean the area rotationally once per week. "Aamasamuha" have actively participated the cleanliness programs. Dustbins have been placed in many places throughout the village by the village committees and ACAP. The people here are self-motivated to make their environment clean, green and healthy, ultimately making the village worth destination for the tourists seeking a peaceful clean environment, rich biodiversity and authentic cultural heritage.

\section{Signboards on trekking routes}

Signboards have been placed along the trekking routes going to Poon hill from Nayapul by the Annapurna Conservation Area Project (ACAP). Such signboards are of great help to the trekkers as it indicates the right direction in every twist and turns along with time to reach the Poon hill through the Ghorepani village.

\section{Trails establishment}

Different stony trails leading to Poon hill have been established from the Ghorepani village. Such stony trails provide good trekking opportunities for visitors as well as facilitate the mule headers to walk easily. There are different trail improvement activities done by the village committees and ACAP. There is a good stony trail now all over the trekking route.

\section{Awareness programmes}

Different awareness programs to the local people have been conducted by the Nepal Tourism Board and ACAP for the establishment and management of ecotourism activities. These programs have different significance and directly or indirectly related to the attraction of tourists. But the awareness programs are decreasing nowadays.

Various other management strategies, such as plantations on barren lands, water resources conservation, forest resources conservation, and community forest management trainings, have been conducted in Ghorepani village. According to the village management committee, some of 
the future programs regarding the development and promotion of ecotourism in the area include housing improvement, organic farming, support for museum establishment, improvement in communication and promotion of the area.

\section{Local people's ranking on tourism management activities}

Local people were asked about tourism management activities conducted in the village and were asked to rank them accordingly. The local people ranked cleanliness program as the most conducted tourism management activities in the area, followed by trail establishment and improvement, signboards on trekking routes, and then eco-club formation (Table 1).

Table 1: Local people's ranking on tourism management activities

\begin{tabular}{|l|c|c|}
\hline Tourism management activities & Mean Rank & Standard Deviation \\
\hline Cleanliness program & 2.05 & 1.030 \\
\hline Trail establishment & 2.16 & 1.001 \\
\hline Signboards in trekking routes & 2.26 & .921 \\
\hline Eco club formation & 4.34 & 1.236 \\
\hline Hospitality management training & 4.89 & 1.203 \\
\hline Awareness program & 5.08 & 1.194 \\
\hline
\end{tabular}

\section{People's perceptions}

\section{The area is suitable for ecotourism}

A majority of the respondents (79 percent) agreed, 13 percent disagreed, and 8 percent were neutral (Figure 12) on the question of the site suitability for ecotourism. Majority of respondents agreed to the statement due to the beautiful natural scenery of snowcapped mountains, morning sunrise, rich cultural heritage, and marvelous Rhododendron forest in the area.

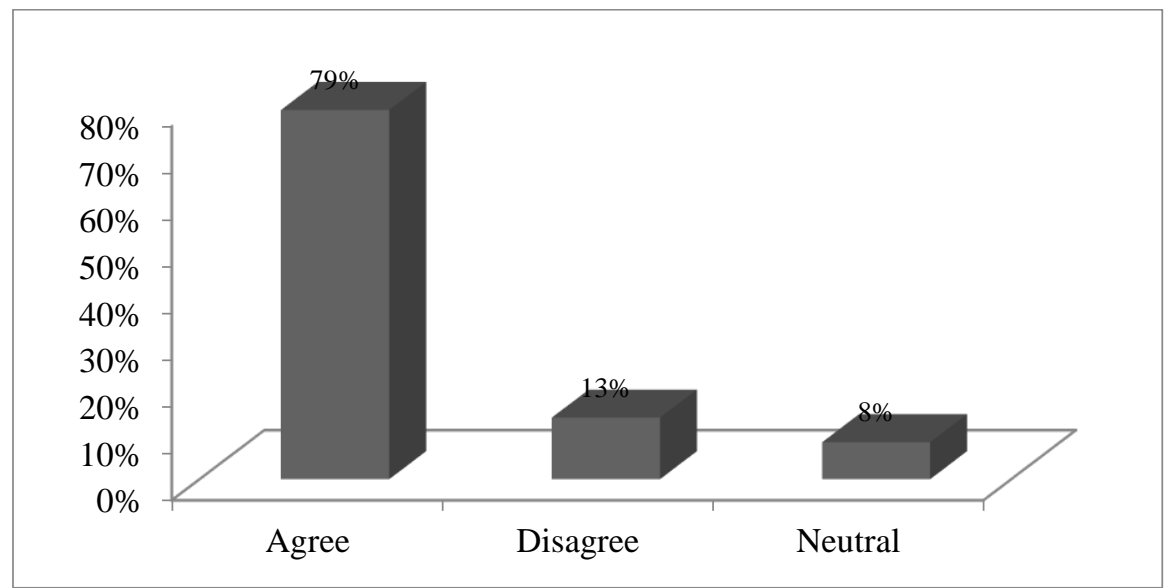

Figure 15: The area is suitable for ecotourism 
The perception of the respondents in the area is suitable for ecotourism was rated on 3-point Likert scale. Three variables such as gender, ethnicity and education were taken. In case of gender, majority of the male and female (72.4 percent) agreed on the statement. Difference among the responses was highly significant ( 0.05 level). In case of ethnicity, 68.66 percent of all ethnic groups agreed on the statement, 17.03 percent disagreed, and 14.26 percent were neutral. Difference among the responses was significant. Similarly, in the case of education category, 71.53 percent agreed on the statement and the differences among the responses vary significantly (Table 2).

Table 2: Perception of the respondents in the area for the site suitability of ecotourism

\begin{tabular}{|c|c|c|c|c|c|c|c|}
\hline \multirow[t]{2}{*}{ Variables } & \multirow[t]{2}{*}{ Category } & \multicolumn{3}{|c|}{ Response in \% within category } & \multirow[t]{2}{*}{$d . f$. } & \multirow[t]{2}{*}{ Value } & \multirow{2}{*}{$\begin{array}{c}p \\
(S / N S)\end{array}$} \\
\hline & & Agree & Disagree & Neutral & & & \\
\hline \multirow[t]{2}{*}{ Gender } & Male & 75.3 & 11.8 & 12.9 & \multirow[t]{3}{*}{2} & \multirow[t]{3}{*}{6.883} & \multirow[t]{3}{*}{$\mathrm{S}$} \\
\hline & Female & 69.5 & 21.4 & 9 & & & \\
\hline \multicolumn{2}{|l|}{ Average } & 72.4 & 16.6 & 10.95 & & & \\
\hline \multirow[t]{3}{*}{ Ethnicity } & Brahmin/Chettri & 50 & 25 & 25 & \multirow[t]{4}{*}{4} & \multirow[t]{4}{*}{13.264} & \multirow[t]{4}{*}{$\mathrm{S}$} \\
\hline & Gurung/Magar & 70.3 & 19 & 10.7 & & & \\
\hline & Others & 85.7 & 7.1 & 7.1 & & & \\
\hline \multicolumn{2}{|l|}{ Average } & 68.66 & 17.03 & 14.26 & & & \\
\hline \multirow[t]{3}{*}{ Education } & Illiterate & 71.4 & 10.7 & 17.9 & \multirow[t]{4}{*}{4} & \multirow[t]{4}{*}{30.364} & \multirow[t]{4}{*}{$\mathrm{S}$} \\
\hline & High school & 73.2 & 23.7 & 3.2 & & & \\
\hline & College degree & 70 & 10 & 20 & & & \\
\hline \multicolumn{2}{|l|}{ Average } & 71.53 & 14.8 & 13.7 & & & \\
\hline
\end{tabular}

$\mathrm{S}=$ significantly difference at 0.05 level, $\mathrm{NS}=$ not significantly differences at 0.05 level

\section{There are sufficient accommodation facilities}

Majority of the people (66 percent) agreed that there are sufficient accommodation facilities in this area while 24 percent disagreed, and 10 percent did not know about it (Figure 13).

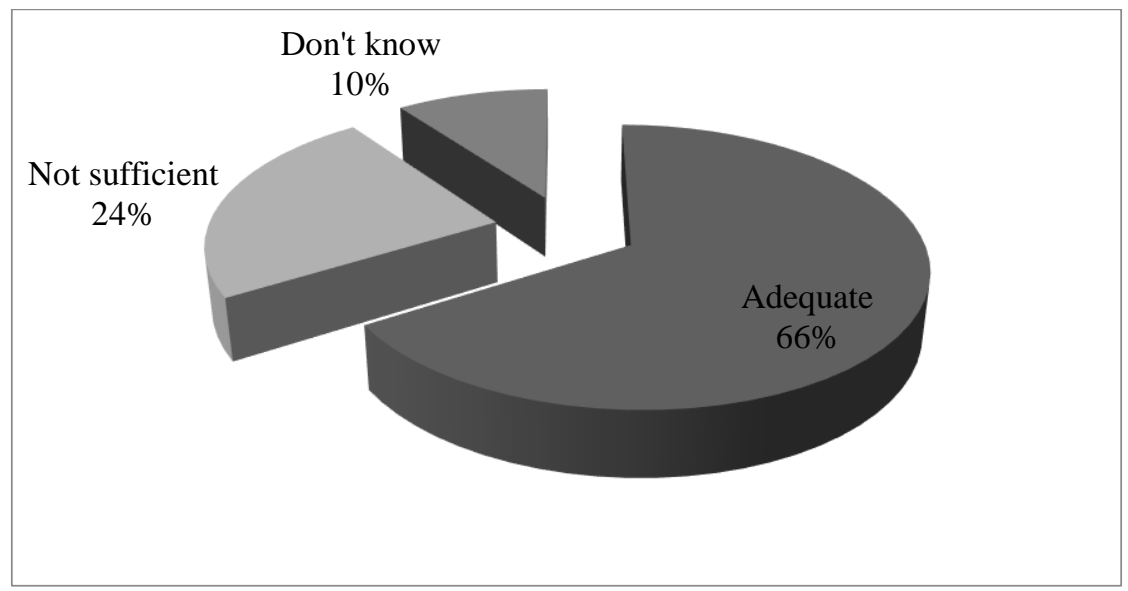

Figure 16: There are sufficient accommodation facilities 


\section{Visitors' satisfaction}

\section{Overall satisfaction}

When the tourists were asked about the overall satisfaction in the area, majority (61 percent) of the tourists said that they were satisfied with this area. Whereas 5 percent of them said that they were extremely satisfied in this area and 34 percent said that they were not satisfied in this area (Figure 14).

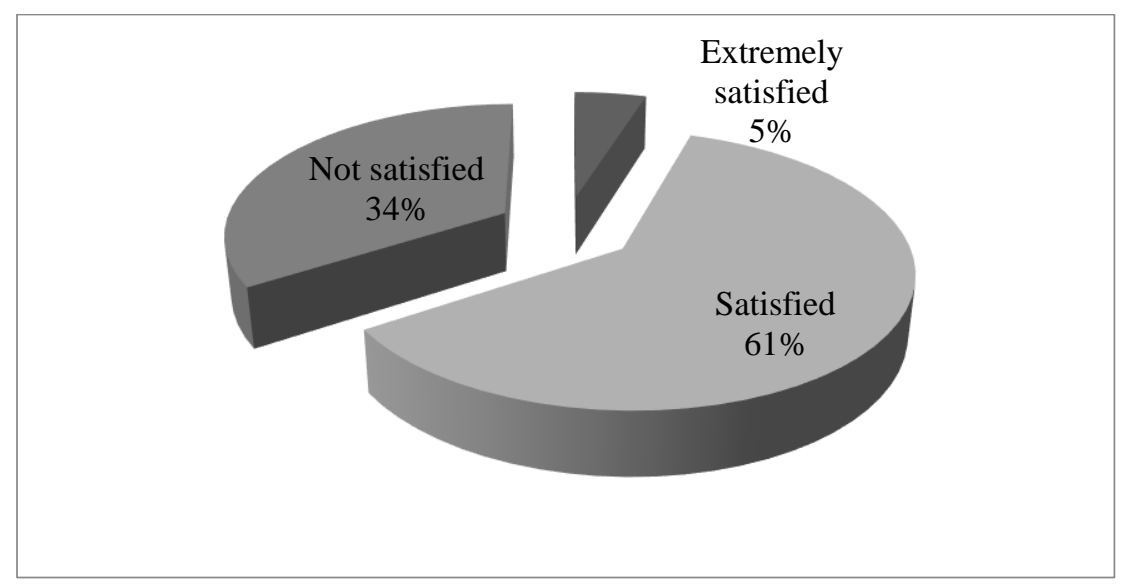

Figure 17: Overall satisfaction of visitors

Again, for the following four statements chi square test was done to know the level of visitor's satisfaction in this area (Table 3, 4, $5 \& 6$ ). The perception of the tourists in the following statements was rated on 3-point Likert scale. Three variables were such as gender, age class, education.

\section{Statement 1: Satisfaction level on management and services of staff}

In case of gender, 70.25 percent of the respondents from male and female category were satisfied on the statement, whereas 13.6 percent of the respondents were not satisfied. Difference among the responses was not significant. In case of education, 68.63 percent of all categories were satisfied on the statement, while 17.93 percent were not satisfied, and 13.43 percent were extremely satisfied. Difference among the responses varies significantly. Similarly, in the case of age class category, 66.96 percent respondents were satisfied on the statement and the difference among the responses was not significant (Table 3).

Table 3: Perception of the respondents for satisfaction level on management and services of staffs

\begin{tabular}{|c|c|c|c|c|c|c|c|}
\hline \multirow[t]{2}{*}{ Variables } & \multirow[t]{2}{*}{ Category } & \multicolumn{3}{|c|}{ Response in \% within category } & \multirow[t]{2}{*}{ d.f } & \multirow[t]{2}{*}{ Value } & \multirow[t]{2}{*}{$p(S / N S)$} \\
\hline & & Ex. Satisfied & Satisfied & Not satisfied & & & \\
\hline \multirow[t]{2}{*}{ Gender } & Male & 9.1 & 77.3 & 13.6 & \multirow[t]{3}{*}{2} & \multirow[t]{3}{*}{4.954} & \multirow[t]{3}{*}{ NS } \\
\hline & Female & 15.8 & 63.2 & 21.1 & & & \\
\hline Average & & 12.45 & 70.25 & 17.35 & & & \\
\hline \multirow[t]{3}{*}{ Education } & Literate & 10 & 80 & 10 & \multirow[t]{3}{*}{4} & \multirow[t]{3}{*}{35.363} & \multirow[t]{3}{*}{$\mathrm{S}$} \\
\hline & High school & 5.3 & 84.2 & 10.5 & & & \\
\hline & $\begin{array}{l}\text { College } \\
\text { degree }\end{array}$ & 25 & 41.7 & 33.3 & & & \\
\hline
\end{tabular}




\begin{tabular}{|l|l|l|l|l|l|l|l|}
\hline \multicolumn{2}{|l|}{ Average } & 13.43 & 68.63 & 17.93 & & & \\
\hline \multirow{4}{*}{ Age class } & Small aged & 11.1 & 77.8 & 11.1 & 4 & 8.621 & NS \\
\cline { 2 - 6 } & Middle aged & 11.5 & 73.1 & 15.4 & & & \\
\cline { 2 - 6 } & Old aged & 16.7 & 50 & 33.3 & & \\
\cline { 2 - 6 } Average & 13.1 & 66.96 & 19.93 & & \\
\hline
\end{tabular}

$\mathrm{S}=$ significantly difference at 0.05 level, $\mathrm{NS}=$ not significantly differences at 0.05 level, Ex. $=$ Extremely.

\section{Statement 2: Satisfaction level on hospitality of the people}

In case of gender, 51.3 percent of the respondents from male and female category were satisfied on the statement, whereas 11.75 percent of the respondents were not satisfied. Difference among the responses was significant. In case of education, 50.86 percent of all categories were satisfied on the statement, 12.4 percent not satisfied, and 36.7 percent were extremely satisfied. Difference among the responses did not vary significantly. Similarly, in the case of age class category, 47 percent respondents were satisfied on the statement and the difference among the responses was significant (Table 4).

Table 4: Perception of respondents for satisfaction level on hospitality of people

\begin{tabular}{|c|c|c|c|c|c|c|c|}
\hline \multirow[t]{2}{*}{ Variables } & \multirow[t]{2}{*}{ Category } & \multicolumn{3}{|c|}{ Response in \% within category } & \multirow[t]{2}{*}{ d.f. } & \multirow[t]{2}{*}{ Value } & \multirow[t]{2}{*}{$p(S / N S)$} \\
\hline & & Ex. Satisfied & Satisfied & $\begin{array}{l}\text { Not } \\
\text { satisfied }\end{array}$ & & & \\
\hline \multirow[t]{2}{*}{ Gender } & Male & 31.8 & 50 & 18.2 & \multirow[t]{3}{*}{2} & \multirow[t]{3}{*}{8.519} & \multirow[t]{3}{*}{$\mathrm{S}$} \\
\hline & Female & 42.1 & 52.6 & 5.3 & & & \\
\hline \multicolumn{2}{|l|}{ Average } & 36.95 & 51.3 & 11.75 & & & \\
\hline \multirow[t]{3}{*}{ Education } & Literate & 40 & 50 & 10 & \multirow[t]{4}{*}{4} & \multirow[t]{4}{*}{1.802} & \multirow[t]{4}{*}{ NS } \\
\hline & High school & 36.8 & 52.6 & 10.5 & & & \\
\hline & $\begin{array}{l}\text { College } \\
\text { degree }\end{array}$ & 33.3 & 50 & 16.7 & & & \\
\hline \multicolumn{2}{|l|}{ Average } & 36.7 & 50.86 & 12.4 & & & \\
\hline \multirow[t]{3}{*}{ Age class } & Small aged & 55.6 & 33.3 & 11.1 & \multirow[t]{4}{*}{4} & \multirow[t]{4}{*}{10.179} & \multirow[t]{4}{*}{$\mathrm{S}$} \\
\hline & Middle aged & 30.8 & 57.7 & 11.5 & & & \\
\hline & Old aged & 33.3 & 50 & 16.7 & & & \\
\hline Average & & 39.9 & 47 & 13.1 & & & \\
\hline
\end{tabular}

$\mathrm{S}=$ significantly difference at 0.05 level, $\mathrm{NS}=$ not significantly differences at 0.05 level 


\section{Statement 3: Satisfaction level on tourism products}

In case of gender, 29.05 percent of the respondents from male and female category were satisfied on the statement, whereas 55.85 percent of the respondents were not satisfied. Difference among the responses was not significant. In case of education, 26.7 percent of all categories were satisfied on the statement, while 58.56 percent were not satisfied, and 14.7 percent were extremely satisfied. Differences among the responses vary significantly. Similarly, in the case of age class category, 29.33 percent of respondents were satisfied on the statement and the difference among the responses was significant, according to the test (Table 5).

Table 5: Perception of respondents for satisfaction level on tourism products

\begin{tabular}{|c|c|c|c|c|c|c|c|}
\hline \multirow[t]{2}{*}{ Variables } & \multirow[t]{2}{*}{ Category } & \multicolumn{3}{|c|}{ Response in \% within category } & \multirow[t]{2}{*}{ d.f. } & \multirow[t]{2}{*}{ Value } & \multirow[t]{2}{*}{$p(S / N S)$} \\
\hline & & Ex. Satisfied & Satisfied & $\begin{array}{l}\text { Not } \\
\text { satisfied }\end{array}$ & & & \\
\hline \multirow[t]{2}{*}{ Gender } & Male & 9.1 & 31.8 & 59.1 & \multirow[t]{3}{*}{2} & \multirow[t]{3}{*}{5.89} & \multirow[t]{3}{*}{ NS } \\
\hline & Female & 21.1 & 26.3 & 52.6 & & & \\
\hline \multicolumn{2}{|l|}{ Average } & 15.1 & 29.05 & 55.85 & & & \\
\hline \multirow[t]{3}{*}{ Education } & Literate & 20 & 10 & 70 & \multirow[t]{4}{*}{4} & \multirow[t]{4}{*}{14.308} & \multirow[t]{4}{*}{$\mathrm{S}$} \\
\hline & High school & 15.8 & 36.8 & 47.4 & & & \\
\hline & $\begin{array}{l}\text { College } \\
\text { degree }\end{array}$ & 8.3 & 33.3 & 58.3 & & & \\
\hline \multicolumn{2}{|l|}{ Average } & 14.7 & 26.7 & 58.56 & & & \\
\hline \multirow[t]{3}{*}{ Age class } & Small aged & 22.2 & 44.4 & 33.3 & \multirow[t]{4}{*}{4} & \multirow[t]{4}{*}{13.56} & \multirow[t]{4}{*}{$\mathrm{S}$} \\
\hline & Middle aged & 11.5 & 26.9 & 61.5 & & & \\
\hline & Old aged & 16.7 & 16.7 & 66.7 & & & \\
\hline Average & & 16.8 & 29.33 & 53.83 & & & \\
\hline
\end{tabular}

$S=$ significantly difference at 0.05 level, $N S=$ not significantly differences at 0.05 level

Statement 4: Satisfaction level on infrastructure, hotels and homestays

In case of gender, 63.75 percent of the respondents from male and female category were satisfied on the statement, whereas 14 percent were not satisfied. Difference among the responses was significant. In case of education, 65.3 percent of all categories were satisfied on the statement, while 16.26 percent were not satisfied, and 18.36 percent were extremely satisfied. Differences among the responses vary significantly. Similarly, in the case of age class category, 56.4 percent of respondents were satisfied on the statement and the difference among the responses was significant, according to the test (Table 6). 
Table 6: Perception of the respondents for satisfaction level on infrastructure, hotels and homestays

\begin{tabular}{|c|c|c|c|c|c|c|c|}
\hline \multirow[t]{2}{*}{ Variables } & \multirow[t]{2}{*}{ Category } & \multicolumn{3}{|c|}{ Response in $\%$ within category } & \multirow[t]{2}{*}{ d.f. } & \multirow[t]{2}{*}{ Value } & \multirow[t]{2}{*}{$p(S / N S)$} \\
\hline & & $\begin{array}{l}\text { Ex. } \\
\text { Satisfied }\end{array}$ & Satisfied & $\begin{array}{l}\text { Not } \\
\text { satisfied }\end{array}$ & & & \\
\hline \multirow[t]{2}{*}{ Gender } & Male & 18.2 & 59.1 & 22.7 & \multirow[t]{3}{*}{2} & \multirow[t]{3}{*}{12.86} & \multirow[t]{3}{*}{$\mathrm{S}$} \\
\hline & Female & 26.3 & 68.4 & 5.3 & & & \\
\hline \multicolumn{2}{|l|}{ Average } & 22.25 & 63.75 & 14 & & & \\
\hline \multirow[t]{3}{*}{ Education } & Literate & 10 & 60 & 30 & \multirow[t]{4}{*}{4} & \multirow[t]{4}{*}{34.297} & \multirow[t]{4}{*}{$\mathrm{S}$} \\
\hline & High school & 36.8 & 52.6 & 10.5 & & & \\
\hline & $\begin{array}{l}\text { College } \\
\text { degree }\end{array}$ & 8.3 & 83.3 & 8.3 & & & \\
\hline \multicolumn{2}{|l|}{ Average } & 18.36 & 65.3 & 16.26 & & & \\
\hline \multirow[t]{3}{*}{ Age class } & Small aged & 11.1 & 66.7 & 22.2 & \multirow[t]{4}{*}{4} & \multirow[t]{4}{*}{21.355} & \multirow[t]{4}{*}{$\mathrm{S}$} \\
\hline & $\begin{array}{l}\text { Middle } \\
\text { aged }\end{array}$ & 19.2 & 69.2 & 11.5 & & & \\
\hline & Old aged & 50 & 33.3 & 16.7 & & & \\
\hline \multicolumn{2}{|l|}{ Average } & 26.76 & 56.4 & 16.8 & & & \\
\hline
\end{tabular}

$\mathrm{S}=$ significantly difference at 0.05 level, $\mathrm{NS}=$ not significantly differences at 0.05 level

\section{Conclusion}

This article mainly emphasizes on the possibilities and issues of ecotourism development and people's perception towards ecotourism in the study area. Majority of the respondents' educational qualification was up to high school and their major occupation was tourism. Only few people were involved in agriculture activities. Most of the respondents were of age around 35-45 years. Regarding the facilities and services concerning tourism in the study area, the facilities/services such as trekking trails, homestays, etc. were available for the visitors. Apart from the existing features and activities there were lots of opportunities for ecotourism development through view tower, establishment of cultural museums, bird watching, camping, etc. However, no year-round transportation and proper communication are the main limiting factors to promote ecotourism in the area. There is a great need for visitors' information centres, promotion and advertisement of the area for tourism. According to the respondents, the numbers of tourists visiting in this area has been declining year by year and the main causes are unstable condition of the country and lack of promotion. Number of domestic tourists visit this area has been increasing, mainly for trekking, research and other specific purposes like trainings, tours, etc.

Management activities such as different trainings related to homestay, cleanliness programs, hospitality management, awareness programs, environmental education have been conducted by both management authorities as well as local people themselves. However, there are still many problems that need to be resolved. Different capacity building trainings and awareness programs should be organized for the local peoples to enhance their tourism related activities. Attitude of the 
respondents was positive for majority of the statements towards ecotourism perceptions. There was a significant difference in the perception among the users according to gender, ethnicity and education level in some of the statements i.e., the area is suitable for ecotourism. Overall, the perception of the local people was positive towards ecotourism. An attitude of the visitors was positive for majority of the statements towards ecotourism satisfaction. There was a significant difference in the perception of tourists about satisfaction level according to gender, education and age class in some of statements i.e., management and services of staff, hospitality of the people shows the overall satisfaction of the tourists in this area. Hence, it is recommended that the management officials of Ghorepani village, Annapurna Conservation Area Project (ACAP) and Tourism Board of Nepal should carefully study the theoretical and practical basis of ecotourism in the world as well as apply it to tourism development. Ghorepani village is nature-based ecotourism that can bring many benefits to the conservation of natural resources and the development of the local community.

\section{References}

Acharya, B.P. and Halpenny, E.A. (2013). Homestays as an alternative tourism product for sustainable community development: A case study of women-managed tourism product in rural Nepal. Tourism Planning and Development, 10(4): 367-387.

Amati, C. (2013). "We all voted for it": experiences of participation in community-based ecotourism from the foothills of Mt Kilimanjaro. Journal of Eastern African Studies, 7(4): 650-670. Doi: https://doi.org/10.1080/17531055.2013.841023

Baral, N., Stern, M.J. and Hammett, A.L. (2012). Developing a scale for evaluating ecotourism by visitors: a study in the Annapurna Conservation Area, Nepal. Journal of Sustainable Tourism, 20(7): 975-989. Doi: https://doi.org/10.1080/09669582.2012.663379

Baral, N. (2014). Evaluation and resilience of ecotourism in the Annapurna Conservation Area, Nepal. Environmental Conservation, 41(1): 84-92. Doi: https://doi.org/10.1017/S0376892913000350

Beza, Z.B. and Berhan, D. (2017). Challenges and prospects of community-based ecotourism development in Lake Zengena and its environs, North West Ethiopia. African Journal of Hospitality Tourism and Leisure, 6(3): 1-12.

Bhattacharya, D., Sarkar, R. and Choudhury, B. (2012). Irresponsible ecotourism practices flanking the best national park in India: A multivariate analysis. SIT Journal of Management, 1(1): $1-27$.

Bhusal, N.P. (2007). Chitwan National Park: a prime destination of eco-tourism in Central Tarai Region, Nepal. The Third Pole: Journal of Geography Education, 70-75. Doi: https://doi.org/10.3126/ttp.v5i0.1956

Blamey, R.K. (2000). The Principles of Ecotourism (5) in Weaver, D.B. (Eds). The Encyclopedia of Ecotourism. Willington, UK: CABI Publication.

Butler, R. and Boyd, S.W. (2000). Tourism and national parks. Chichester, UK: Wiley.

Cao, H., Tang, M., Deng, H. and Dong, R. (2014). Analysis of management effectiveness of natural reserves in Yunnan Province, China. International Journal of Sustainable Development and World Ecology, 21(1): 77-84. Doi: https://doi.org/10.1080/13504509.2013.786764

Cater, C. and Cater, E. (2015). Ecotourism: International Encyclopedia of the Social and Behavioral Sciences (2 ${ }^{\text {nd }}$ Edition). Elsevier, pp.105-109. Doi: https://doi.org/10.1016/B978-0-08-097086-8.91071-7 
CBS (2012). National population and housing census 2011. Kathmandu: Central Bureau of Statistics, 1.

Cheung, L.T. and Jim, C.Y. (2014). Expectations and willingness-to-pay for ecotourism services in Hong Kong's conservation areas. International Journal of Sustainable Development and World Ecology, 21(2): 149-159. Doi: https://doi.org/10.1080/13504509.2013.859183

Cusack, D. and Dixon, L. (2006). Community-based ecotourism and sustainability: cases in Bocas del Toro Province, Panama and Talamanca, Costa Rica. Journal of Sustainable Forestry, 22(1-2): 157-182.

Farrell, B.H. and Runyan, D. (1991). Ecology and Tourism. Annals of Tourism Research, 18 (1): 26-40.

Guha, I. and Ghosh, S. (2007). Does tourism contribute to local livelihoods? A case study of tourism, poverty and conservation in the Indian Sundarbans. Kathmandu: SANDEE.

Hetzer, N.D. (1965). Environment, tourism, culture. Links, 1(3).

Khatri-Chhetri, A. and Parajuli, R.B.T. (2014). Tourism and its impact on livelihood in Manaslu conservation area, Nepal. Environment, Development and Sustainability, 16(5): 10531063. Doi: https://doi.org/10.1007/s10668-013-9512-7

Khatri-Chhetri. A, Rijal, K. and Sapkota, R.P. (2015). Role of ecotourism in environmental conservation and socioeconomic development in Annapurna conservation area, Nepal. International Journal of Sustainable Development \& World Ecology, 22(3), 251258. Doi: https://doi.org/10.1080/13504509.2015.1005721

KMTNC (2002). Ongoing projects of KMTNC: Manaslu Conservation Area Project (MCAP). Online: http://www.southasia.com/Kingmah/tonproj.htm\#5, Accessed on September $16,2002$.

Lamsal, P. (2011). Protection forest: a new dimension for biodiversity conservation, sustainable forest management and livelihood improvement. The Initiation, 4: 111-114.

Lee, T.H. and Jan, F.H. (2019). Can community-based tourism contribute to sustainable development? Evidence from residents' perceptions of the sustainability. Tourism Management, 70: 368-380. Doi: https://doi.org/10.1016/j.tourman.2018.09.003

MoTCA (2012). Nepal Tourism Statistics 2012. Kathmandu: Ministry of Tourism and Civil Aviation.

Nath, T.K. and Alauddin (2006). Sitakunda Botanical Garden and Eco-park, Chittagong, Bangladesh: Its impacts on a rural community. The International Journal of Biodiversity Science and Management, 2(1): 1-11. Doi: https://doi.org/10.1080/17451590609618095

Nepal S.K. (1997). Sustainable tourism, protected areas and livelihood needs of local communities in developing countries. International Journal of Sustainable Development \& World Ecology, 4: 123-135.

Nepal, S.K. and Weber, K.W. (1995). Managing resources and resolving conflicts: national parks and local people. International Journal of Sustainable Development \& World Ecology, 2(1): 11-25. Doi: https://doi.org/10.1080/13504509.1995.10590662

Nguyen, H.P. (2020). Ecological tourism in Tram Chim National Park: potential, opportunity and challenge. Geology, Ecology, and Landscapes, pp.1-10. DOI: https://doi.org/10.1080/24749508.2020.1742501

Ormsby, A. and Mannle, K. (2006). Ecotourism benefits and the role of local guides at Masoala National Park, Madagascar. Journal of Sustainable Tourism, 14(3): 271-287. Doi: https://doi.org/10.1080/09669580608669059

Poyyamoli, G. (2018). Ecotourism Policy in India: Rhetoric and Reality. Grassroots Journal of Natural Resources, 1(1): 46-61. 
Shrestha, U.S. (2001). Bio-diversity Conservation and Eco-tourism: A Case Study from Lang National Park. Himalayan Review, 32: 41-54.

Silva, G. and McDill, M.E. (2004). Barriers to ecotourism supplier success: A comparison of agency and business perspectives. Journal of Sustainable Tourism, 12(4): 289-305. Doi: https://doi.org/10.1080/09669580408667239

Singh, B.P. and Upadhyay, R. (2011). Ecotourism and its Effect on Wildlife of Panchmarhi Biosphere Reserve. African Journal of Environment Science and Technology, 5(9): 717 721.

Smolčić Jurdana, D. (2009). Specific knowledge for managing ecotourism destinations. Tourism and Hospitality Management, 15(2): 267-278.

Stem, C.J., Lassoie, J.P., Lee, D.R. and Deshler, D.J. (2003). How 'eco' is ecotourism? A comparative case study of ecotourism in Costa Rica. Journal of Sustainable Tourism, 11(4): 322-347. Doi: https://doi.org/10.1080/09669580308667210

Sukhdev, P., Stone, S. and Nuttall, N. (2010). Green economy, developing countries success stories. St-Martin-Bellevue: United Nation Environment Programme (UNEP).

Tseng, M.L., Wu, K.J., Lee, C.H., Lim, M.K., Bui, T.D. and Chen, C.C. (2018). Assessing sustainable tourism in Vietnam: A hierarchical structure approach. Journal of Cleaner Production, 195: 406-417. Doi: https://doi.org/10.1016/j.jclepro.2018.05.198

UNEP (2013). Tourism: trends, challenges and opportunities. Green Economy and Trade. United Nations Environment Programme, pp.259-291.

UNWTO (2010). Tourism will contribute to solutions for global climate change and poverty challenges. Berlin: United Nation World Trade Organization Press and Communications Department.

Upadhayaya, P.K., Müller-Böker, U. and Sharma, S.R. (2011). Tourism amidst armed conflict: Consequences, copings, and creativity for peacebuilding through tourism in Nepal. The Journal of Tourism and Peace Research, 1(2): 22-40.

Weaver, D. (2001a). Ecotourism. Australia: John Wiley and Sons.

Weaver, D. (2001b). Mass tourism and alternative tourism in the Caribbean. Tourism and the less developed world: Issues and case studies, pp. 161-174.

Winson, A. (2006). Ecotourism and sustainability in Cuba: Does socialism make a difference? Journal of Sustainable Tourism, 14(1): 6-23. Doi: https://doi.org/10.1080/09669580608668588

Yogi, H.N. (2010). Ecotourism and sustainability-opportunities and challenges in the case of Nepal (Master's thesis). University of Uppsala, Sweden, pp. 60.

Zambrano, A.M.A., Broadbent, E.N. and Durham, W.H. (2010). Social and environmental effects of ecotourism in the Osa Peninsula of Costa Rica: the Lapa Rios case. Journal of Ecotourism, 9(1): 62-83. Doi: https://doi.org/10.1080/14724040902953076 